\title{
MODEL KONTROL MANAJEMEN LAKTASI DI UPT PUSKESMAS PAHANDUT KOTA PALANGKARAYA
}

\author{
Control Model Of Lactation Management In Pahandut Public Health Center \\ Palangkaraya City
}

\author{
Fitriani Ningsih ${ }^{\text {* }}$ \\ Rizki Muji Lestari ${ }^{2}$ \\ Raynaldi ${ }^{3}$ \\ *123 Prodi Kesehatan \\ Masyarakat, STIKES Eka Harap, \\ Palangka Raya, Kalimantan \\ Tengah, Indonesia \\ *email:
}

feghanz@gmail.com

\section{Kata Kunci: \\ Stroke \\ Kekuatan \\ Genggaman tangan}

\section{Keywords:}

Stroke

Strength

Hand grip

\begin{abstract}
Abstrak
Dalam pemberian ASI perlu suatu upaya manajemen laktasi yang dilakukan oleh ibu untuk menunjang keberhasilan menyusui secara ekslusif, karena pada hakikatnya manajemen laktasi dimulai pada masa kehamilan, setelah persalinan, dan masa menyusui bayi. Manajemen laktasi adalah suatu tatalaksana yang mengatur agar keseluruhan proses menyusui bisa berjalan dengan lancar dan sukses mulai dari ASI diproduksi sampai proses bayi menghisap dan menelan ASI. Oleh sebab itu, perlu adanya dukungan dalam pemenuhan ASI bagi bayi yaitu dengan model kontrol manajemen laktasi yang bertujuan agar manajemen laktasi dapat dilakukan dengan baik sehingga pemberian ASI secara ekslusif dapat terlaksana. Desain penelitian ini menggunakan desain penelitian Quasy Experiment dengan rancangan Pre-Post-test Control Group Design, dengan menggunakan sampel 30 responden ibu nifas yang ada di UPT Puskesmas Pahandut Kota Palangka Raya. Kelompok ini dibagi menjadi 15 responden sebagai kelompok intervensi dan 15 responden sebagai kelompok kontrol. Pada penelitian ini menggunakan uji statistik T-Test Paired. Hasil uji statistik juga diperoleh dari tiap variabel kontrol nilai $P$ Value penyuluhan $(0,000)$, dukungan keluarga $(0,000)$, kebijakan ASI Ekslusif $(0,000)$, perawatan payudara $(0,017)$ dan hypno breastfeeding $(0,048)$. $P$ Value $<$ dari a $(0,05)$ artinya variabel penyuluhan, dukungan keluarga, kebijakan ASI Ekslusif, perawatan payudara dan hypno breastfeeding sangat efektif dalam membantu meningkatkan produksi ASI
\end{abstract}

\begin{abstract}
In breastfeeding, it is necessary to carry out lactation management efforts by the mother to support the success of exclusive breastfeeding, because in essence lactation management starts during pregnancy, after childbirth, and during the breastfeeding period of the baby. Lactation management is a management that regulates the entire breastfeeding process to run smoothly and successfully, from the production of breast milk to the process of the baby sucking and swallowing breast milk. Therefore, it is necessary to support the fulfillment of breastfeeding for infants, namely the control model of lactation management which aims to ensure that lactation management can be carried out properly so that exclusive breastfeeding can be carried out. The design of this study used a Quasy Experiment research design with a Pre-Post-test Control Group Design, using a sample of 30 post-partum mothers in Pahandut Health Center, Palangka Raya City. This group was divided into 15 respondents as the intervention group and 15 respondents as the control group. In this study using the Paired T-Test statistical test. The results of statistical tests were also obtained from each control variable, the value of $P$ value for counseling $(0.000)$, family support $(0.000)$, exclusive breastfeeding policy $(0.000)$, breast care $(0.017)$ and hypno breastfeeding (0.048). P value < of a $(0.05)$ means that the variable of counseling, family support, exclusive breastfeeding policy, breast care and hypno breastfeeding are very effective in helping increase milk production.
\end{abstract}

(C) year The Authors. Published by Institute for Research and Community Services Universitas Muhammadiyah Palangkaraya. This is Open Access article under the CC-BY-SA License (http://creativecommons.org/licenses/by-sa/4.0/). DOI: https://doi.org// 0.33084/jsm.vxix.xxx.

\section{PENDAHULUAN}

Air Susu Ibu (ASI) eksklusif adalah ASI yang diberikan kepada bayi sejak dilahirkan selama enam bulan, tanpa menambahkan dan/atau mengganti dengan makanan atau minuman lain (Monika, 20I5). Kolostrum yang tekandung di dalam ASI kaya akan antibodi karena mengandung protein untuk daya tahan tubuh dan pembunuh kuman dalam jumlah tinggi sehingga pemberian ASI eksklusif dapat mengurangi risiko kematian pada bayi. Pada hari pertama sampai hari 
ketiga ASI mengandung kolostrum yang berwarna kekuningan selanjutnya pada hari keempat sampai hari kesepuluh ASI mengandung immunoglobulin, protein, dan laktosa lebih sedikit dibandingkan kolostrum tetapi lemak dan kalori lebih tinggi dengan warna susu lebih putih. Selain mengandung zat-zat makanan, ASI juga mengandung zat penyerap berupa enzim tersendiri yang tidak akan menganggu enzim di usus. Susu formula tidak mengandung enzim sehingga penyerapan makanan tergantung pada enzim yang terdapat di usus bayi (Kementrian Kesehatan RI, 2018). Dalam pemberian ASI perlu suatu upaya manajemen laktasi yang dilakukan oleh ibu untuk menunjang keberhasilan menyusui secara ekslusif, karena pada hakikatnya manajemen laktasi dimulai pada masa kehamilan, setelah persalinan, dan masa menyusui bayi. Manajemen laktasi adalah suatu tatalaksana yang mengatur agar keseluruhan proses menyusui bisa berjalan dengan lancar dan sukses mulai dari ASI diproduksi sampai proses bayi menghisap dan menelan ASI (Maryunani, 20I8).

Secara nasional, cakupan bayi yang mendapatkan ASI eksklusif pada tahun 2017 sebesar 6I,33\%. Angka ini sudah melampaui target Renstra tahun 2017 yaitu $44 \%$. Sedangkan cakupan pemberian ASI eksklusif pada provinsi Kalimantan Tengah sebesar 58, I I\%. Pada tahun 2018 cakupan bayi yang mendapatkan ASI eksklusif di Indonesia sedikit meningkat yaitu $68,74 \%$ dengan target renstra $47 \%$ sedangkan cakupan pemberian ASI eksklusif pada provinsi Kalimantan Tengah sedikit menurun yaitu sebesar 53,64\% (Kementrian Kesehatan RI, 2018). Berdasarkan data Profil Dinas Kesehatan Kota Palangka Raya Tahun 2016 cakupan bayi yang mendapatkan ASI eksklusif hanya $14,99 \%$ dan pada tahun 2017 sedikit meningkat yaitu sebesar 16,79\% angka ini masih jauh dari target Restra Provinsi Kalimantan Tengah yaitu sebesar 80\% (Dinas Kesehatan Kota Palangka Raya, 2018). Hal ini memperlihatkan bahwa cakupan ASI Eksklusif di Kota Palangka Raya sangat rendah. Cakupan ASI yang rendah merupakan tanda bahwa kesadaran para ibu dalam memberikan ASI masih perlu ditingkatkan. Anggapan bahwa menyusui adalah cara yang kuno serta alasan ibu bekerja, takut kehilangan kecantikan, tidak disayangi lagi oleh suami dan gencarnya promosi perusahaan susu formula di berbagai media massa juga merupakan alasan yang dapat mengubah kesepakatan ibu untuk menyusui bayinya sendiri, serta menghambat terlaksananya proses laktasi. Selain itu, kendala ibu dalam menyusui ada dua faktor yaitu faktor internal kurangnya pengetahuan ibu tentang manajemen laktasi dan faktor eksternal ASI belum keluar pada hari-hari pertama sehingga ibu berpikir perlu tambah susu formula, ketidakmengertian ibu tentang kolostrum, banyak ibu yang masih beranggapan bahwa ASI ibu kurang gizi dan kualitasnya tidak baik. Oleh sebab itu, perlu adanya dukungan dalam pemenuhan ASI bagi bayi. Kualitas menyusui salah satu hal yang harus diperhatikan oleh ibu sehingga produksi ASI optimal. Oleh sebab itu, maka perlu dilakukan penelitian dengan melakukan penelitian mengenai model kontrol manajemen laktasi dengan tujuan agar manajemen laktasi dapat dilakukan dengan baik sehingga pemberian ASI secara ekslusif dapat terlaksana

\section{METODOLOGI}

\section{Jenis Penelitian}

Desain penelitian ini menggunakan desain penelitian Quasy Experiment dengan rancangan PrePosttest Control Group Design. Penelitian ini dilakukan untuk mengetahui pengaruh perlakuan terhadap produksi ASI sebelum dan sesudah perlakuan (Notoatmodjo, 2012a). Cara mengetahuinya yaitu dengan membandingkan produksi ASI sebelum dan sesudah perlakuan pada kelompok intervensi dan kelompok kontrol. Pada kelompok intervensi ibu akan diberikan perlakuan secara sengaja mengenai penyuluhan tentang Laktasi selama 4 hari, kerja sama dengan keluarga untuk memberikan support dalam memberikan ASI saja selama 4 hari, penyampaian informasi mengenai kebijakan ASI eklklusif selama 2 hari, diajarkan dan dilatih untuk perawatan payudara selama 
4 hari dan diajarkan serta dilatih untuk melakukan Hypno Breastfeeding secara mandiri dengan audio visual yang sudah disediakan selama 4 hari. Sedangkan pada kelompok kontrol tidak diberikan secara sengaja, hanya saja semua informasi mengenai penyuluhan laktasi, dukungan keluarga, kebijakan ASI, perawatan payudara dan hypno breasfeeding sudah pernah didapatkan melalui tenaga kesehatan dan media massa.

\section{Lokasi dan Waktu Penelitian}

Lokasi penelitian ini di Wilayah Kerja UPT Puskesmas Pahandut Kota Palangka Raya dan Waktu penelitian dilaksanakan pada bulan Juli sd September 2020.

\section{Populasi dan Sampel}

Populasi dalam penelitian ini adalah ibu nifas yang ada diwilayah kerja UPT Puskesmas Pahandut Kota Palangka Raya. Dan besar sampel sebanyak 30 responden ibu nifas yang ada di UPT Puskesmas Pahandut Kota Palangka Raya. Kelompok ini dibagi menjadi 15 responden sebagai kelompok intervensi dan 15 responden sebagai kelompok control.

\section{Metode Analisis Data}

Analisis dalam penelitian ini berupa analisis bivariate yaitu untuk melihat apakah ada pengaruh yang bermakna antara variabel independen dengan variabel dependen (Sugiyono, 2016). Pada penelitian ini menggunakan uji statistik T-Test Paired

\section{HASIL DAN PEMBAHASAN}

HASIL

Tabel I. Hasil Uji Normalitas Data Pada Variabel Kontrol Manajemen Laktasi di Puskesmas Pahandut Kota Palangka Raya Tahun 2020

\begin{tabular}{lccc}
\hline \multirow{1}{*}{ Data } & \multicolumn{3}{c}{ Saphiro-Wilk } \\
\cline { 2 - 4 } & Statistic & df & $\boldsymbol{P}$ Value \\
\hline $\begin{array}{l}\text { Produksi Asi Sebelum } \\
\text { (intervensi I) }\end{array}$ & 0,947 & 30 & 0,136 \\
\hline $\begin{array}{l}\text { Produksi ASI Sesudah } \\
\text { (intervensi I) }\end{array}$ & 0,940 & 30 & 0,089 \\
\hline $\begin{array}{l}\text { Produksi Asi Sebelum } \\
\text { (intervensi 2) }\end{array}$ & 0,940 & 30 & 0,089 \\
\hline $\begin{array}{l}\text { Produksi ASI Sesudah } \\
\text { (intervensi 2) }\end{array}$ & 0,940 & 30 & 0,090 \\
\hline
\end{tabular}

\begin{tabular}{lccc}
\hline $\begin{array}{l}\text { Produksi Asi Sebelum } \\
\text { (intervensi 3) }\end{array}$ & 0,940 & 30 & 0,090 \\
\hline $\begin{array}{l}\text { Produksi ASI Sesudah } \\
\text { (intervensi 3) }\end{array}$ & 0,935 & 30 & 0,066 \\
\hline $\begin{array}{l}\text { Produksi Asi Sebelum } \\
\text { (intervensi 4) }\end{array}$ & 0,935 & 30 & 0,066 \\
\hline $\begin{array}{l}\text { Produksi ASI Sesudah } \\
\text { (intervensi 4) }\end{array}$ & 0,952 & 30 & 0,186 \\
\hline $\begin{array}{l}\text { Produksi Asi Sebelum } \\
\text { (intervensi 5) }\end{array}$ & 0,940 & 30 & 0,090 \\
\hline $\begin{array}{l}\text { Produksi ASI Sesudah } \\
\text { (intervensi 5) }\end{array}$ & 0,951 & 30 & 0,178 \\
\hline \begin{tabular}{l} 
Dari tabel di atas dapat dilihat bahwa dengan jumlah \\
\hline
\end{tabular}
\end{tabular}
sampel 30 responden didapatkan nilai $P$ value rata-rata $>$ a $(0,05)$ dengan ketentuan nilai $P$ Value $>$ a $(0,05)$ yang berarti data berdistribusi normal. Sehingga pada penelitian ini, uji statistik yang digunakan tetap menggunakan uji Paired $T$ test. Adapun hasil uji statistik pada penelitian ini, sebagai berikut:

Tabel 2. Variabel Kontrol Manajemen Laktasi di Puskesmas Pahandut tentang Model Kontrol Manajemen Laktasi di UPT Puskesmas Pahandut Kota Palangka Raya Tahun 2020

\begin{tabular}{lccc}
\hline \multicolumn{1}{c}{ Variabel } & \multicolumn{1}{c}{$\begin{array}{c}\text { Mean } \\
\text { Pengeluaran }\end{array}$} & P Value \\
& \begin{tabular}{l} 
ASI (dalam cc) \\
\cline { 2 - 3 }
\end{tabular} & \\
\cline { 2 - 3 } $\begin{array}{l}\text { Pre } \\
\text { hari) }\end{array}$ & Post & \\
\hline $\begin{array}{l}\text { Dukungan } \\
\text { keluarga (4 hari) }\end{array}$ & 82,50 & 86,7 & 0,000 \\
\hline $\begin{array}{l}\text { Kebijakan ASI } \\
\text { Ekslusif (2 hari) }\end{array}$ & 91,3 & 91,3 & 0,000 \\
\hline $\begin{array}{l}\text { Perawatan } \\
\text { Payudara (4 hari) }\end{array}$ & 91,3 & 152,0 & 0,017 \\
\hline $\begin{array}{l}\text { Hypno } \\
\text { Breastfeeding (4 } \\
\text { hari) }\end{array}$ & 152,0 & 212,0 & 0,048 \\
\hline
\end{tabular}

Berdasarkan tabel di atas dapat disimpulkan bahwa responden yang diberikan penyuluhan selama hari nilai rata-rata pengeluaran ASI sebelum dan sesudah terdapat peningkatan pengeluaran ASI sebesar 4,2 cc; selanjutnya pada responden yang diberikan dukungan keluarga secara intens terdapat peningkatan pengeluaran ASI sebelum dan sesudah yaitu rata-rata 4,6 cc; pada ibu yang diberikan informasi kebijakan ASI Ekslusif ada peningkatan rata-rata pengeluaran ASI sebelum dan seudah sebesar 3,4 cc; pada responden 
yang diberikan panduan perawatan payudara secara rutin mengalami peningkatan rata-rata pengeluaran ASI sebelum dan sesudah yaitu $60,7 \mathrm{cc}$ dan pada responden yang diberikan panduan Hypnobreast Feeding juga mengalami peningkatan rata-rata pengeluaran ASI sebelum dan sesudah sebanyak 60 cc. Hasil uji statistik juga diperoleh dari tiap variabel kontrol nilai $P$ Value penyuluhan $(0,000)$, dukungan keluarga $(0,000)$, kebijakan ASI Ekslusif (0,000), perawatan payudara $(0,017)$ dan hypno breastfeeding $(0,048)$. P Value $>$ dari a $(0,05)$ artinya variabel penyuluhan, dukungan keluarga, kebijakan ASI Ekslusif, perawatan payudara dan hypno breastfeeding sangat efektif dalam membantu meniungkatkan produksi ASI.

Pada penelitian ini juga terdapat variabel atau faktor lain yang dianggap sebagai faktor lain yang mempengaruhi pengeluaran produksi ASI ibu. Variabel yang dimaksud adalah pendidikan, tingkat stress, paritas dan motivasi. Variabel ini akan di uji dengan menggunakan Uji regresi liniar Berganda dengan tujuan untuk melihat faktor yang paling dominan yang dapat mempengaruhi variabel kontrol untuk manajemen laktasi Adapun hasil uji statistik sebagai berikut:

Tabel 3 Pemodelan pertama (seleksi Bivariate) faktor lain yang mempengaruhi produksi ASI di di Puskesmas Pahandut tentang Model Kontrol Manajemen Laktasi di UPT Puskesmas Pahandut Kota Palangka Raya Tahun 2020

\begin{tabular}{lc}
\hline Variabel & P Value \\
\hline Pendidikan & 0,000 \\
\hline Stress & 0,007 \\
\hline Paritas & 0,019 \\
\hline Motivasi & 0,000
\end{tabular}

Berdasarkan tabel di atas nilai $\mathrm{P}$ Value pendidikan $(0,000)$, stress $(0,007)$, paritas $(0,019)$ dan motivasi $(0,000)$. Dari hasil ini dapat disimpulkan bahwa tiap variabel $<0,25$ artinya tiap variabel bisa melanjutkan ke multivariate

Tabel 4 Pemodelan Kedua (Pemodelan Multivariate) faktor lain yang mempengaruhi produksi ASI di di Puskesmas Pahandut tentang Model
Kontrol Manajemen Laktasi di UPT Puskesmas Pahandut Kota Palangka Raya Tahun 2020

\begin{tabular}{lcc}
\hline Variabel & Coefficients $\boldsymbol{B}$ & $\boldsymbol{P}$ Value \\
\hline Pendidikan & -34.492 & .157 \\
\hline Motivasi & -77.539 & .001 \\
\hline Paritas & -18.679 & .354 \\
\hline Stress & -1.525 & .897 \\
\hline
\end{tabular}

Berdasarkan tabel di atas, nilai $\mathrm{P}$ Value yang $>0,05$ adalah pendidikan $(0,157)$, paritas $(0,354)$ dan stress $(0,897)$ sehingga harus dikeluarkan dalam pemodelan. Variabel yang dikeluarkan adalah variabel yang memiliki nilai $\mathrm{P}$ Valuie yang terbesar yaitu stres.

Tabel 5 Pemodelan Ketiga (Pemodelan Multivariate) faktor lain yang mempengaruhi produksi ASI di di Puskesmas Pahandut tentang Model Kontrol Manajemen Laktasi di UPT Puskesmas Pahandut Kota Palangka Raya Tahun 2020

\begin{tabular}{lcccc}
\hline Variabel & $\begin{array}{c}\text { Coefficients } \\
\text { B Post }\end{array}$ & $\begin{array}{c}\text { Coefficie } \\
\text { nts B Pre }\end{array}$ & Perubahan & $\begin{array}{c}\boldsymbol{P} \\
\text { Value }\end{array}$ \\
\hline Pendidikan & -35.000 & -34.492 & $1,4 \%$ & 0,138 \\
\hline Motivasi & -78.200 & -77.539 & $3,6 \%$ & 0,000 \\
\hline Paritas & -19.360 & -18.679 & $0,8 \%$ & 0,310
\end{tabular}

Berdasarkan tabel di atas, perhitungan perubahan nilai

Coefficients B masing-masing variabel tidak ada yang berubah melebihi $10 \%$ dengan demikian variabel stres dapat dikeluarkan dari model. Selanjutnya keluarkan variabel yang nilai $P$ Value nya $>0,05$ yaitu pendidikan dan paritas. Yang terbesar adalah paritas, sehingga variabel ini dikeluarkan pada pemodelan berikutnya.

Tabel 6 Pemodelan Keempat (Pemodelan Multivariate) faktor lain yang mempengaruhi produksi ASI di di Puskesmas Pahandut tentang Model Kontrol Manajemen Laktasi di UPT Puskesmas Pahandut Kota Palangka Raya Tahun 2020

\begin{tabular}{lcccc}
\hline Variabel & $\begin{array}{c}\text { Coefficients } \\
\text { B Post }\end{array}$ & $\begin{array}{c}\text { Coefficients } \\
\text { B Pre }\end{array}$ & $\begin{array}{c}\text { Perubahan } \\
\text { Coefficients }\end{array}$ & $\begin{array}{c}\boldsymbol{P} \\
\text { Value }\end{array}$ \\
\hline Pendidikan & -49.491 & -34.492 & $39 \%$ & .011 \\
\hline Motivasi & -73.563 & -77.539 & $5,9 \%$ & .001
\end{tabular}

Berdasarkan tabel di atas, perhitungan perubahan nilai

Coefficients B masing-masing variabel melebihi 10\% dengan demikian variabel paritas dimasukan kembali pada pemodelan terakhir.

Tabel 7 Pemodelan Terakhir (Pemodelan Multivariate) faktor lain yang 
mempengaruhi produksi ASI di di Puskesmas Pahandut tentang Model Kontrol Manajemen Laktasi di UPT Puskesmas Pahandut Kota Palangka Raya Tahun 2020

$\begin{array}{cccc}\text { Variabel } & \begin{array}{c}\text { Coefficients } \\ \text { B }\end{array} & \text { Beta } & \text { P Value }\end{array}$

\begin{tabular}{llll}
\hline Pendidikan & -35.000 & -.264 & 0,138 \\
\hline Motivasi & -78.200 & -.574 & 0,000 \\
\hline Paritas & -19.360 & -.148 & 0,310 \\
\hline
\end{tabular}

Berdasarkan tabel di atas dapat diketahui bahwa variabel yang besar peranannya terhadap pengeluaran produksi ASI adalah variabel motivasi. Sehingga responden yang diberikan penyuluhan, kebijakan tentang ASI Ekslusif, dukungan keluarga, perawatan payudara dan hypnobreastfeeding akan mempengaruhi pengeluan ASI setelah dikontrol variabel pendidikan, motivasi dan paritas.

\section{PEMBAHASAN}

Manajemen laktasi merupakan usaha atau cara yang dilakukan untuk mencapai keberhasilan menyusui. Menguasai manajemen laktasi merupakan hak dan kewajiban ibu dan calon ibu. Calon ibu dapat mempelajari manajemen laktasi sebagai bagian dari usaha mempersiapkan persalinan dan menyusui sehingga komplikasi dan hal-hal yang menghambat proses menyusui dapat dicegah (Roesli, 20I2). Ruang Lingkup manajemen laktasi adalah periode postnatal, antara lain ASI eksklusif, teknik menyusui, memeras ASI, memberikan ASI peras, menyimpan ASI peras, pemenuhan gizi selama periode menyusui. Semua tahapan pada manajemen laktasi adalah penting dan berperan untuk keberhasilan ASI eksklusif, sehingga semua tahap harus dipersiapkan dengan baik supaya ASI eksklusif berjalan dengan sukses adalah motivasi bidan, konseling dan perawatan payudara (Maryunani, 2018). Berdasarkan hasil penelitian ini model kontrol yang dapat diterapkan dalam melakukan manajemen ASI pada ibu menysui sebagai berikut:

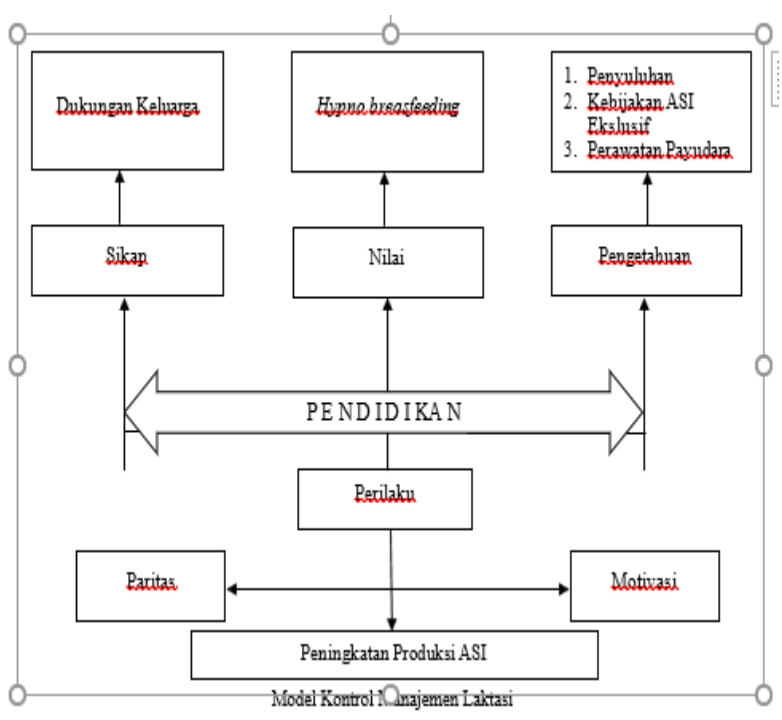

Penyuluhan tentang laktasi yang diberikan kepada ibu dapat mempengaruhi produksi ASI ibu. Selama 4 hari responden yang diberikan penyuluhan sebanyak 3 kali dengan melakukan evalusi berulang terkait hambatan maupun kesulitan dalam memberikan ASI dapat mempengaruhi pengeluaran produksi ASI hal ini dapat ditunjukan dengan nilai rata-rata pengeluaran ASI sebelum dan sesudah terdapat peningkatan pengeluaran ASI sebesar 4,2 cc serta hasil uji statistik menunjukkan bahwa penyuluhan efektif untuk meingkatkan produksi ASI ( $P$ Value 0,000). Menurut Notoatmodjo (2012) Pemberian ASi ekslusif kepada bayi merupakan perilaku kesehatan yang berkaitan dengan aktifitas ibu dalam memberikan ASI pada bayi. Perilaku kesehatan sebagaimana dijelaskan Green dalamNotoatmodjo (20I2), salah satu faktor utama yaitu pengetahuan. Secara teoritis pengetahuan atau kognitif merupakan dominan yang sangat penting dalam membentuk tindakan seseorang. Tanpa mengesampingkan faktor lain, diketahui bahwa pengetahuan yang baik mengenai ASI akan berdampak positif terhadap Pemberian ASI. Dengan demikian, melalui penyuluhan maka ibu tersebut dapat memperoleh keterangan atau informasi yang benar tentang laktasi. Melalui pemahaman tersebut, maka ibu dapat mempersiapkan diri supaya mereka benar-benar dapat menyusui bayinya secara eksklusif; persiapan- 
persiapan tersebut dapat berupa mengkonsumsi makanan yang dapat memacu pengeluaran asi secara optimal, atau upaya lain berupa penyiapan atau perawatan payudara ibu, sehingga secara fisik benarbenar siap untuk menyusui. Hal ini juga didukung dengan penelitian Sutomo \& Kuswandi (2014) yang menyatakan bahwa ada pengaruh intervensi penyuluhan terhadap pemberian ASI ( $P$ Value $=0,000)$. Penyuluhan merupakan faktor yang harus dipertimbangkan dalam upaya mengubah perilaku seseorang; dengan diberi penyuluhan yang lebih intensif, maka seseorang akan menjadi lebih mengerti dan memahami untuk bertindak sesuai yang diharapkan dari isi penyuluhan bersangkutan.

Dukungan keluarga secara intens dapat meningkatkan pengeluaran ASI. Hal ini dibuktikan dengan adanya perubahan nilai rata-rata sebelum dan sesudah diberikan dukungan secara intens yaitu rata-rata 4,6 cc. Dan hasil uji statistik menunjukkan dukungan keluarga yang intens dapat meningkatkan produksi ASI ibu ( $P$ Value 0,000). Dukungan keluarga sangat berperan dalam sukses tidaknya menyusui. Semakin besar dukungan yang didapat untuk terus menyusui maka akan semakin besar pula kemampuan ibu untuk dapat bertahan terus untuk menyusui. Dalam hal ini dukungan keluarga sangat besar pengaruhnya, seorang ibu yang kurang mendapatkan dukungan dari keluarganya menjadi tidak percaya diri dan kurang motivasi untuk memberikan ASI eksklusif (Atikah, 2014). Dukungan keluarga memberikan kontribusi yang besar terhadap keinginan ibu untuk menyusui bayi dan juga memberikan pengaruh kuat terhadap pengambilan keputusan untuk tetap menyusui (Ratnasari et al., 2017). Hal ini sejalan dengan penelitian Saraung (2017) bahwa dukungan keluarga mempunyai hubungan dengan suksesnya produksi ASI dan pemberian ASI eksklusif kepada bayi. Dukungan keluarga adalah dukungan untuk memotivasi ibu memberikan ASI saja kepada bayinya sehingga meningkatkan frekuensi produksi ASI. Suami dan keluarga dapat berperan aktif dalam pemberian ASI dengan cara memberikan dukungan emosional atau bantuan praktis lainnya.

Informasi kebijakan ASI Ekslusif juga dapat meingkatkan produksi ASI, hal ini dibuktikan dengan adanya peningkatan rata-rata produksi ASI sebesar 3,4 cc setelah diberikan informasi tentang kebijakan ASI Ekslusif. Hasil uji statistik menunjukkan nilai $P$ Value 0,000 artinya informasi kebijakan ASI ekslusif efektif untuk meningkatkan produksi ASI. Gerakan untuk memberikan ASI secara eksklusif dinilai masih kurang menggema dan minim dukungan dari banyak pihak. Padahal, pemerintah telah membuat peraturan yang menjamin hak anak untuk mendapatkan ASI seperti yang tertuang dalam Undang-undang Nomor 36 Tahun 2009 Tentang Kesehatan, dan juga Peraturan Pemerintah (PP) Nomor 33 Tahun 2012 Tentang ASI Eksklusif. Asas keseimbangan mengandung makna bahwa pemberian ASI eksklusif mempunyai konsekuensi pemenuhan hak dan kewajiban. Pemenuhan hak dalam hal ini adalah hak anak untuk mendapatkan ASI eksklusif dan kewajiban Ibu untuk memberikan ASI eksklusif kecuali atas indikasi medis, dimana keluarga, masyarakat, pemerintah dan pemerintah daerah wajib mendukung proses pemberian ASI eksklusif tersebut. Pihak-pihak yang sudah disebutkan tadi tidak boleh dengan sengaja menghalangi proses pemberian ASI eksklusif tersebut. Asas manfaat dalam pemberian ASI ekslusif harus dipilah berdasarkan manfaat bagi bayi, manfaat bagi lbu, manfaat bagi keluarga, serta manfaat bagi negara. ASI bagi bayi akan memberikan manfaat dalam hal pemenuhan kebutuhan nutrisi, meningkatkan daya tahan tubuh, meningkatkan kecerdasan, mengurangi infeksi, dll. Sedangkan bagi Ibu akan mengurangi perdarahan setelah melahirkan, mengecilkan rahim, mengurangi kemungkinan terkena kanker, menjarangkan kehamilan, dll. Bagi keluarga akan menghemat pengeluaran karena tidak perlu membeli susu formula, praktis karena tidak perlu menyiapkan alat-alat untuk menyusui, kebahagiaan bertambah karena menjarangkan kehamilan, sehingga akan mendekatkan hubungan bayi dengan keluarga. Dan yang 
terakhir manfaat ASI bagi negara akan menurunkan angka kesakitan dan kematian bayi, mengurangi subsidi untuk biaya kesehatan, menghemat devisa negara, meningkatkan produktivitas ibu pekerja serta akan meningkatkan kualitas generasi penerus bangsa (Zainafree, 2016). Pemberian informasi mengenai kebijakan ASI Ekkslusif akan berdampak positif karena akan menumbuhkan kesadaran dari para lbu untuk merasa 'harus' memberikan ASI ekslusif saat bayinya lahir serta dukungan dari pihak keluarga untuk mendorong para lbu memberikan ASI eksklusif. Kedua, kesadaran moral para tenaga kesehatan dengan sepenuh hati memberikan edukasi dan informasi yang jelas kepada para lbu (PP No 33, 20I2).

Perawatan payudara secara rutin mengalami peningkatan rata-rata pengeluaran ASI sebelum dan sesudah yaitu 60,7 cc. Hasil uji statistik diperoleh nilai $P$ Value 0,0I7 artinya perawatan payudara sangat efektif untuk meningkatkan produksi ASI. Perawatan payudara bertujuan untuk memelihara kebersihan payudara, memperbanyak atau memperlancar pengeluaran ASI. Tujuan perawatan untuk memperlancar produksi ASI dengan merangsang kelenjar-kelenjar air susu melalui pemijatan, mencegah bendungan ASI atau pembengkakan payudara, melenturkan dan menguatkan putting (Manuaba, 20I5). Hasil penelitian sejalan dengan penelitian Tyfani (2017) yang menyatakan bahwa perawatan payudara dapat meningkatkan produksi ASI sehingga akan memperlancar ASI ibu nifas. Semakin sering dan tuyin ibu melakukan perawatan payudara maka ASI pun akan lancar. Pelaksanaan perawatan payudara sebaiknya dimulai sedini mungkin yaitu setelah bayi dilahirkan dan dilakukan dua kali sehari.

Hypno breastfeeding juga mengalami dapat meningkatkan rata-rata pengeluaran ASI, hal ini dibuktikan dengan adanya peningkatan rata-rata pengeluaran ASI sebelum dan sesudah sebanyak $60 \mathrm{cc}$. Hasil uji statistik juga diperoleh nilai $P$ Value $\quad 0,048$ artinya hypno breastfeeding sangat efektif dalam membantu meningkatkan produksi ASI. Hypno breastfeeding adalah teknik relaksasi untuk membantu kelancaran proses menyusui. Caranya memasukkan kalimat-kalimat afirmasi yang positif yang membantu proses menyusui di saat ibu dalam keadaan rileks atau sangat berkonsentrasi pada suatu hal. Hasil penelitian ini pun sejalan dengan penelitian Rahmawati (2017) yang menyatakan bahwa Hypno breastfeeding dapat meningkatkan produksi ASI dengan nilai $P$ value 0,000 , pada kelompok yang diberikan intervensi nilai mean sebelum diberikan Hypno breastfeeding sebesar $210 \mathrm{cc}$ dan nilai mean sesudah diberikan Hypno breastfeeding sebesar 255 cc. Hal ini munenunjukkan bahwa terdapat peningkatan produksi ASI pada ibu nifas setelah diberikan Hypno breastfeeding. Pelaksanaan Hypno breastfeeding dengan mendengarkan suara secara berulangkali oleh ibu sehingga tertanam kuat dalam pikiran bawah sadar ibu dan setiap saat selalu membangkitkan motivasi dan kepercayaan diri ibu untuk menyusui. Tingkat kepercayaan diri menyusui ibu yang tinggi akan membentuk pola pemberian ASI eksklusif sehingga meskipun ketika terkendala ibu bekerja, ibu akan berupaya untuk memberikan ASI dengan sering menyusui bayi saat bersama bayi dan melakukan pemerahan ASI saat ibu bekerja. Hypno breastfeeding akan membuat membuat seseorang dalam kondisi trance atau membawa alam pikiran dari conscious mind ke subconscious mind. Dalam penelitian ini, tahap rileksasi dicapai melalui tehnik relaksasi otot, relaksasi nafas dan relaksasi pikiran. Semua tehnik relaksasi didapatkan dengan mengikuti instruksi terapis/penghipnotis yang suaranya telah terekam dengan iringan alunan musik yang lembut sehingga ibu akan merasa lebih rileks.

Dari beberapa variabel di atas tentunya tidak lepas dari faktor lain seperti pendidikan, paritas dan motivasi. Pada penelitian ini menunjukkan bahwa, pada analisis pemodelan multivariate variabel yang sangat mempengaruhi atau mengontrol variabel lain adalah motivasi. Pada penelitian peneliti sebelumnya Ningsih (2019) menyatakan bahwa motivasi berhubungan 
dengan produksi ASI. Keberhasilan menyusui didukung oleh kesiapan psikologis ibu yang dipersiapkan sejak masa kehamilan. Keinginan dan motivasi yang kuat untuk menyusui bayinya akan mendorong ibu untuk selalu berusaha menyusui bayinya dalam kondisi apapun. Dengan motivasi yang kuat. Seorang ibu tidak akan mudah menyerah meskipun ada masalah dalam proses menyusui bayinya. Dengan demikian maka ibu akan selalu menyusui bayinya sehingga rangsangan pada puting akan mempengaruhi let down refleks sehingga aliran ASI menjadi lancar. Selain itu paritas juga mempengaruhi produksi ASI ibu $\mathrm{Hal}$ ini didukung dengan penelitian yang dilakukan oleh Lestari (2013), mayoritas ibu yang memberikan ASI secara ekslusif adalah ibu multipara (memiliki anak lebih dari I) dibandingkan primipara (memiliki I anak). Ibu multipara erat kaitannya dengan adanya pengetahuan yang didapat dari pengelaman menyusui sebelumnya. Ketika seorang ibu sebelumnya sudah pernah mengalami menyusui, maka hal itu akan menjadi pengetahuan baginya ketika menyusui kembali dimasa selanjutnya. Ketika sudah belajar dari pengalaman sebelumnya, maka dimungkinkan bahwa ibu dapat mengatasi permasalah permasalahan yang mungkin saja dihadapi. Tingkat pendidikan menentukan mudah tidaknya seseorang menyerap dan memahami pengetahuan yang mereka peroleh, pada umumnya semakin tinggi pendidikan seseorang makin semakin baik pula pengetahuannya. Tingkat pendidikan seseorang akan berpengaruh dalam pemberian respon terhadap sesuatu yang datang dari luar.orang yang perdidikan tinggi akan memberikan respon yang lebih rasional terhadap informasi yang datang dan alasan berfikir sejauh mana keuntungan yang mungkin akan mereka peroleh dari gagasan tersebut. Bagi sebagian ibu,menyusui merupakan tindakan yang alamiah dan naruliah. Oleh karena itu, mereka beranggapan bahwa menyusui tidak perlu di pelajari namun kebanyakan ibu kurang menyadari penting nya ASI sebagai makanan utama bayi. mereka hanya mengetahui ASI adalah makanan yang diperlukan bayi tanpa memperhatikan aspek lainnya (Prasetyono 2013)

\section{KESIMPULAN}

Hasil uji statistik juga diperoleh dari tiap variabel kontrol nilai $P$ Value penyuluhan $(0,000)$, dukungan keluarga $(0,000)$, kebijakan ASI Ekslusif $(0,000)$, perawatan payudara $(0,017)$ dan hypno breastfeeding $(0,048)$. $P$ Value < dari a $(0,05)$ artinya variabel penyuluhan, dukungan keluarga, kebijakan ASI Ekslusif, perawatan payudara dan hypno breastfeeding sangat efektif dalam membantu meningkatkan produksi ASI.

Selain itu variabel yang besar peranannya terhadap pengeluaran produksi ASI adalah variabel motivasi. Sehingga responden yang diberikan penyuluhan, kebijakan tentang ASI Ekslusif, dukungan keluarga, perawatan payudara dan hypnobreastfeeding akan mempengaruhi pengeluan ASI setelah dikontrol variabel pendidikan, motivasi dan paritas.

Berdasarkan hasil penelitian ini model kontrol yang dapat diterapkan dalam melakukan manajemen ASI pada ibu menysui sebagai berikut:

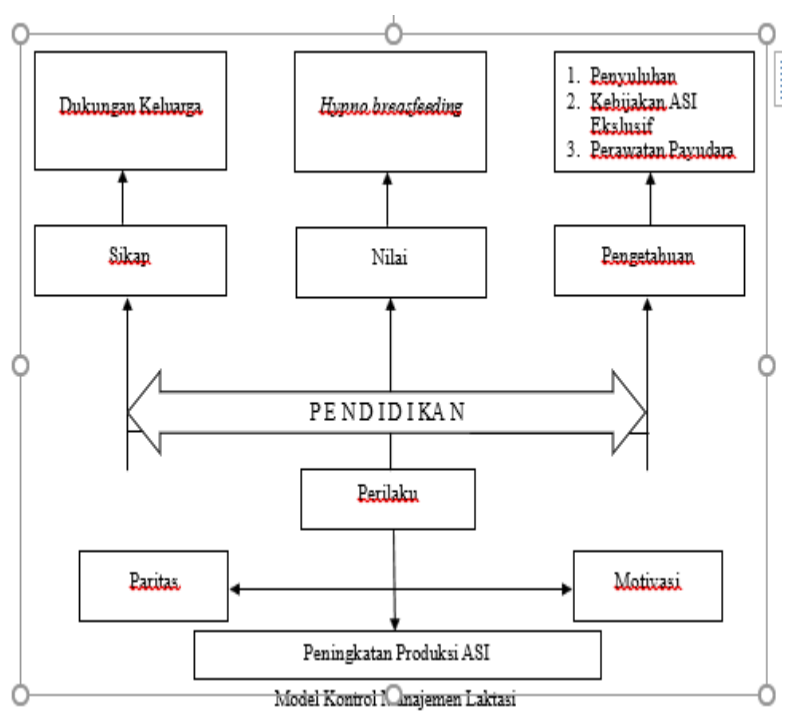

\section{UCAPAN TERIMA KASIH}

Penulis sadar banyak hambatan dalam proses penyusunan proposal ini, dikarenakan keterbatasan kemampuan penulis sendiri. Oleh Karena itu penulis 
sampaikan banyak terimakasih kepada semua pihak yang telah memberikan bantuannya, utamanya kepada yang terhormat:

I. Kementerian Riset Dan Teknologi/ Badan Riset Dan Inovasi Nasional

2. Kepala Badan Penelitian dan Pengembangan Provinsi Kalimantan Tengah

3. Kepala Dinas Kesehatan Kota Palangka Raya

4. Kepala UPT Puskesmas Pahandut Kota Palangka Raya

5. Ketua STIKes Eka Harap

\section{REFERENSI}

I. Monika, F. B. (20I5). Buku Pintar ASI dan Menyusui. In Buku Pintar ASI dan Menyusuian Menyusui.

2. Kementrian Kesehatan RI. (2018). Profil Kesehatan Indonesia 2018 Kemenkes RI. http://www.depkes.go.id/resources/download/pus datin/profil-kesehatan-indonesia/Data-danInformasi_Profil-Kesehatan-Indonesia-2018.pdf

3. Dinas Kesehatan Kota Palangka Raya. (20I8). Profil Kesehatan Kota Palangka Raya.

4. Maryunani, A. (2018). Asuhan Neonatus, Bayi, Balita \& Anak Pra-Sekolah. In Asuhan Neonatus, Bayi, Balita \& Anak Pra-Sekolah.

5. Notoatmodjo, S. (20I2). Metodologi Penelitian Kesehatan. Jakarta: Rineka Cipta.

6. Notoatmodjo, S. (20I2). Promosi Kesehatan dan Perilaku Kesehatan (edisi revisi 20I2). In Jakarta: rineka cipta.

7. Sugiyono. (20/6). Metode Penelitian Kuantitatif, Kualitatif, Dan R\&D. Jakarta: Alfabeta, cv.

8. Roesli, U. (20/2). Panduan: inisiasi menyusu dini: plus asi eksklusif. Pustaka Bunda.

9. Sutomo, O., \& Kuswandi, K. (20|4). Pengaruh Intervensi Pemberian Penyuluhan Asi Eksklusif Pada Ibu Hamil Trimester lii Terhadap Pemberian Asi Eksklusif Di Daerah Perkotaan Kabupaten Lebak Tahun 2012. Jurnal Medikes (Media Informasi Kesehatan).

https://doi.org// 0.36743/medikes.v Ii2.129

10. Atikah, P.; E. R. (20|4). Kapita Selekta: ASI Dan Menyusui.
II. Ratnasari, D., Paramashanti, B. A., \& Yugistyowati, A. (2017). Hubungan dukungan keluarga dengan riwayat asi eksklusif pada ibu bekerja di Kabupaten Bantul [Skripsi]. Yogyakarta: Universitas Alma Ata.

12. Saraung, M. W., Rompas, S., \& Bataha, Y. B. (2017). Analisis Faktor-Faktor Yang Berhubungan dengan Produksi ASI Pada lbu Postpartum di Puskesmas Ranotana Weru. Jurnal Keperawatan, 5(2).

I3. Manuaba, Ida Bagus Gde. (20/5). Pengantar Kuliah Obtetri. EGC. Jakarta

14. Tyfani, M. B., Utami, N. W., \& Susmini, S. (20/7). Hubungan Perawatan Payudara Terhadap Kelancaran Asi Pada Ibu Post-Partum Di Kelurahan Tlogomas Kecamatan Lowokwaru Kota Malang. Nursing News: Jurnal Ilmiah Keperawatan, 2(I).

15. Rahmawati, A., \& Prayogi, B. (2017). Hypnobreastfeeding untuk Meningkatkan Produksi Asi pada lbu Menyusui Yang Bekerja. Research Report, 48-53

16. Ningsih, F., \& Lestari, R. M. (2019). Efektifitas Kombinasi Pijat Oksitosin dan Hypno Breastfeeding terhadap Optimalisasi Produksi ASI pada lbu Nifas. Jurnal Surya Medika (JSM), 5(I), I74-I87.

17. Prasetyono, D. (20I3). Buku Pintar ASI Eksklusif, Pengenalan Praktek dan Kemanfaatannya, Yogyakarta. 